\title{
Why people earn more: Learn how
}

\section{Book Title:}

Pay: Why People Earn What They Earn and What You Can Do Now to Make More

\section{Book Cover:}

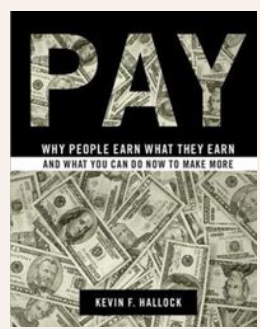

ISBN:

9781107014985

Publisher:

Cambridge University Press, 2012, US\$14.36*

*Book price at time of review

\section{Review Title:}

Why people earn more: Learn how

Reviewer:

Jenni Gobind ${ }^{1}$

\section{Affiliation:}

${ }^{1}$ Department of Industrial

Psychology and People

Management, University of

Johannesburg, South Africa

Email:

jgobind@uj.ac.za

\section{Postal address:}

Postnet Suite 333, Private

Bag X17, Weltevreden Park

1715, South Africa

How to cite this article: Gobind, J. (2014). Why people earn more: Learn how. SA Journal of Human Resource Management/ SA tydskrif vir Menslike Hulpbronbestuur 12(1), Art. \#614, 2 pages. http:// dx.doi.org/10.4102/sajhrm. v12i1.614

\section{Read online:}

Kevin F. Hallock, labour economist at Cornell University, explains to a general audience how their pay is determined. Arguments are based primarily on lessons from labour economics and human resources management. The author skilfully explains why people earn what they earn and how they can earn more in both the short and the long run. It describes wages, wage differences across groups, wage inequality, how organizations set pay and why, executive and 'superstar' pay, the difference between pay and 'total rewards' (including benefits, opportunities for growth, colleagues and working conditions), compensation in non-profits and the differences between the cost of compensation to organisations and the value employees place on that compensation. It also offers tips on what an individual can do to do to earn more.

The book follows a literary fiction structure written in four parts, each part layering on the previous ones and drawing in the interest of the reader. Hallock engages the reader's attention in the intricacies of pay through his casual and skilful use of anecdotes based on his personal experience in jobs from professional cucumber picker to Ivy League professor:

So, what does Hallock do? Instead of trying to cover everything and to do so in depth, his approach has allowed him to selectively choose topics that he feels are most compelling and to focus on engaging the reader around these select topics. He skilfully hones in on a policy area, highlights a theoretical idea or two, and then describes one or a few empirical studies that are especially relevant and that provide pertinent evidence on the policy question (Gerhart, 2010, p. 526).

Hillock makes reference to the American context and yet the parallels with remuneration in South Africa are unmistakeable and almost mysterious.

Chapter 1 of Part I includes a brief synopsis of the 13 chapters to follow. Chapter 2 is about wages, wage distribution and wage inequality. For a South African reader, Chapter 2 is of interest as it touches on aspects of South African pay that are current and often misconstrued. Hillock provides insight into compensation differences and the difference in levels of pay between men, women, the young and African Americans. This chapter discusses the extraordinarily wide distribution of income in the world with specific reference to the United States. Hillock discusses reasons for the dramatic level of income inequality and whether it is likely to change in the future. Chapter 3 discusses who makes what and their characteristics. This chapter commences with a discussion on wage differences by occupation. This includes a list of occupations and a discussion of the level of compensation and benefits in those jobs, as well as the characteristics of people holding those jobs, including amongst others, age, education, gender, levels of experience and average seniority on the job. Chapter 4 discusses the difference between wages and total compensation, and asks a very pertinent question: Is there a difference between the cost of compensation to organisations and the value of that compensation to employees? Hillock goes on to discuss employer cost of employee compensation, what is understood by total compensation and employers' perception of how employees value compensation.

Part II of the book focuses mostly on pay structure and the process large organisations utilise when establishing their pay structure. Chapter 5 discusses basic strategy and compensation strategy, starting with a basic framework looking at the world of work Total Rewards Model. Hillock relies on a hypothetical case to expound on the why salaries should be kept a secret. Midway through the chapter Hillock discusses strategy, factors that influence strategy and the understanding, business and functioning of compensation. Chapter 6 delves into job analysis, job evaluation and internal comparisons. The chapter explains what is in a job and organising job analysis, how and what to collect when gathering data for a job analysis and job evaluation. Hillock expounds on job evaluation basics and the ways to consider job evaluation, including ranking and point systems. Internal comparisons of job evaluation are briefly touched on. Relying on a passage from the bible, Hillock is able to show that relative comparisons can matter as much as or even more than absolute comparisons. Chapter 7 discusses the importance of collecting the right comparison

Copyright: () 2014. The Authors. Licensee: OpenJournals Publishing. This work is licensed under the Creative Commons Attribution License. 
data and matching internal structure to external market data. For instance, Chapter 7 touches on what goes into determining what organisations pay using data surveys. Chapter 8 focuses on the highly paid; although the chapter looks at athletes and entertainers, the chapter specifically investigates CEOs of publicly traded, for-profit companies. Hillock begins the chapter with the ways executives are paid. He provides an overview of the basic kinds of pay levels, mix and pay distributions for publicly traded firms in the United States. In the latter part of Chapter 8, Hillock discusses why one should not believe what is written about CEO pay. In so doing, he goes on to unpack executive pay and company size, risk between pay and performance and risk and executive compensation.

Part III concentrates on how people are paid and how much they are paid. Chapter 9 outlines the problems and difficulties of evaluating performance and executive pay. Hillock returns to his favourite anecdote, cucumber picking, which helps to illustrate the best way to pay a person. He touches on a Safelite Glass case study on low productivity and the compensation system. Relying on the Safelite Glass case study, Hillock moves on to discuss performance appraisal and incentive pay. Chapter 10 describes stock and stock options and offers a guide to where they are and are not useful as a way to pay people. Stock options are defined; why organisations offer stock options and how employees value stock options are discussed. Chapter 11 is a relatively short chapter which discusses pay mix and asks the following questions: Why offer benefits? Would employees prefer cash? Chapter 12 takes an international perspective, examining international compensation, culture and methods of paying workers across countries. Chapter 13 touches on compensation in non-profit organisations and the distinction between non-profit organisations and forprofit organisations. Hillock investigates possible reasons for differences in pay between the for-profit and non-profit sectors whilst emphasising pay and performance in nonprofit organisations. His discussion is well supported with empirical findings on the non-profit versus for-profit pay gap. Hillock briefly touches on executive pay in non-profit organisations, gender and race in non-profit organisations and non-profit and international pay.

Part IV is titled 'What you can do to make more and concluding remarks'. Chapter 14 is an open, almost casual discussion on what you can do now to make more now and later, which Hillock describes as 'easy stuff'. Hillock suggests that one should 'ask', do one's homework and be part of the solution. In a bold statement Hillock adds that one should switch employers and get a face-lift or plastic surgery as beautiful people make more money than people who are not so beautiful. In addition to this bold statement, Hillock makes reference to academic literature that suggests that drinking can increase your earnings, that two jobs are better than one and finally to talk to people and be patient. Hillock concludes his book with Chapter 15 with concluding remarks on pay.

I can only concur with Anne Ruddy, president and CEO of WorldatWork that Hillock's book Pay: Why People Earn What They Earn and What You Can Do Now to Make More is:

a truly refreshing read on the complicated and highly emotional world of pay. Dr. Hillock helps make sense of the purpose and approach behind the many components of our (US) pay what and why we make what we do.

His informal style and rhetoric make for an informative read, allowing for easy application and guidance anywhere in the world.

\section{References}

Gerhart, B. (2012). Pay: Why People Earn What They Earn and What You Can Do Now to Make More. By Kevi F. Hallock. Cornell University ILR School ILR Review, 66(2). Retrieved October 07, 2013, from http://digitalcommons.ilr.cornell.edu/cgi/ viewcontent.cgi?article=2960\&context=ilrreview 